\title{
A tribute to Paul S. Frenette (1965-2021)
}

\section{La vraie générosité envers l'avenir con- siste à tout donner au présent.}

(Real generosity toward the future lies in giving all to the present.)

\section{-Albert Camus}

Paul Frenette, MD, an extraordinary physician-scientist, colleague, and friend, died on July 26, 2021, at the age of 56 (Figure 1). Paul was raised in Cap-Santé, Québec, by his father, an elementary school principal, and his mother, a homemaker, along with four siblings. His hometown was a beautiful but sparsely populated village along the St. Lawrence River between Quebec and Montreal. To keep boredom at bay during the summer, Paul and his siblings invented games. The absence of infrastructure was likely fertile ground for the creativity that helped Paul become a great scientist. Although Paul played many sports during his childhood, hockey was far and away his favorite. Paul was a true Philadelphia Flyers fan and appreciated them for their commitment, team spirit, and dedication to the sport. Paul had a keen desire to succeed and the determination to spare no effort to do so in terms of time and energy. No excuse was allowed for not performing at $100 \%$.

At the age of 15, Paul was diagnosed with stage 4 Hodgkin lymphoma, which caused him to miss many hours of classes and studies due to a plethora of treatments to manage his condition. Nevertheless, he finished first in his class in tenth grade. After all, cancer was not an excuse to finish second! His favorite field for competition had now become school. He graduated among the top in medicine at Université Laval, Quebec City, and in 1985 he was awarded a prestigious summer Terry Fox Scholarship, given to only a very few medical students in Canada. He came to the United States to train as a fellow in hematology-oncology at Tufts Medical Center in 1994. He soon met his future wife, Nadine, at a jazz club in Cambridge, Massachusetts. Paul subsequently received his scientific research training at Massachusetts Institute of Technology and Harvard Medical School. Paul deeply enjoyed studying and working, and he was in his element as a researcher.

Paul began his independent research career in 1998 as Assistant Professor at the Mount Sinai School of Medicine in New York City, where he rose to Professor of Medicine in 2007. He was recruited to the Albert Einstein College of Medicine in 2010 to become the Founding Director and Chair of the Ruth L. and David S. Gottesman Institute for Stem Cell and Regenerative Medicine Research, where he recruited key faculty members and established it as a premier stem cell research program. He was also Professor of Medicine and Cell Biology.

Paul was an outstanding and very creative scientist who made seminal contributions to several fields of biomedical science, including the stem cell microenvironment in health and cancer and the vascular biology of sickle cell disease. His laboratory broke new ground in sickle cell disease related to vascular occlusion, cell adhesion, thromboinflammation, neutrophil aging, neutrophil extracellular traps, and the microbiome (1-6). Using intravital microscopy, the group discovered that leukocytes play a direct role in vascular occlusion by capturing circulating sickle red blood cells. They went on to show that a wave of neutrophil activation is involved and that E-selectin mediates this activation, suggesting that selectin inhibitors may be beneficial for treating sickle cell vascular occlusion. His research directly enabled clinical trials in sickle cell disease of rivipansel, olinciguat, and IgG. He shared his authoritative vascular pathobiology perspective in a chapter of the textbook Sickle Cell Disease, published just two months before his death.

Paul's group also made very important contributions to characterizing the bone marrow stem cell niche. They made the paradigm-shifting discovery that the sympathetic nervous system regulates hemato-

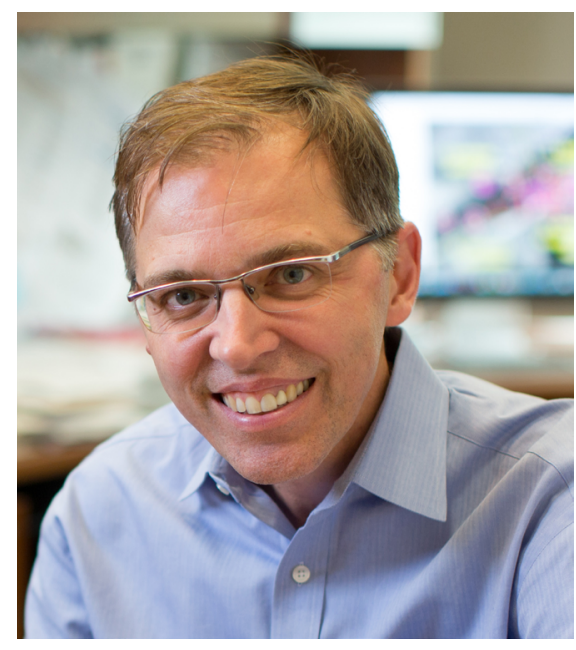

Figure 1. Paul S. Frenette, MD. Image credit: Nadine Frenette.

poietic stem cell egress from the niche and described circadian regulation of hematopoietic stem cell migration from the bone marrow (7-12). Paul's lab identified key stromal constituents of the hematopoietic stem cell niche and demonstrated the important role of macrophages in regulating bone marrow niches. Paul then extended the concept of nervous system control of hematopoietic stem cell migration to understand how cancer cells metastasize by demonstrating that similar signaling exists in prostate cancer models. His lab identified important and distinct functions of the two branches of the autonomic nervous system in prostate cancer progression, showing that the sympathetic nervous system plays a prominent role in cancer initiation, whereas the parasympathetic nervous system (muscarinic receptors) plays a role in spreading of cancer into lymph nodes and distant organs $(13,14)$.

Paul served on the editorial board of Blood, the board of consulting editors of the Journal of Clinical Investigation, and the Medical Advisory Board of the New York Stem Cell Foundation; as chair of a scientific committee of the American Society of Hematology; and on the Sickle Cell Advisory Council of the National Heart, Lung, and Blood Institute and multiple other panels at the NIH. Paul was elected to the American Society for Clinical Inves- 
tigation in 2004 and to the Association of American Physicians in 2010.

Paul's work was gigantic: always a topic of importance, always interesting at the level in basic biology, yet always with a clear connection to medicine. Paul considered himself a doctor first and then a researcher, and his physician training guided him in the topics he studied. It also made him flexible and creative in his approach. The discovery of neural circadian circuits regulating the bone marrow niche came about because of a lighting miscue in the animal facility. It was a mistake, but Paul could see in it a discovery that changed many people's perception of a niche and its connection to complex organism-level physiology. He delighted in a quirky, odd moment leading to a fundamental insight. That joy carried over to how he cared for his mentees and colleagues. There were no moments with Paul that went without his broad, warm smile, lilting laugh, and often a twist of irony. He conducted even disagreement with a light, kind touch and did service to the field without fanfare or ego. His contributions will forever carry his distinct signature of joie de vivre.

In science, Paul was the Happy Warrior, generous in spirit, virtuously coveting truth, and competing every day to attract the best students and to fund, publish, and share his work. His talent, coupled with his endless determination, elevated him to among the best in his field. The Latin maxim that he often heard from his father during child- hood was "excelsior," which means always higher, always further, and this ethos continued to resonate throughout Paul's life.

Paul was a devoted father to his children, Clara and Albéric. An amateur enologist, he enjoyed visiting wineries and vineyards and meeting vintners. $\mathrm{He}$ also had a passion for music, and he and Nadine often went to concerts by the New York Philharmonic. Paul will be deeply missed by his friends, colleagues, and family. His legacy will live on through his discoveries and students, and his exemplary life of living and working to the fullest.

\section{Acknowledgments}

We thank Nadine Frenette, Jérôme Frenette, David Scadden, Greg Kato, and Mark Gladwin for sharing their memories and insights.

\section{Johanna P. Daily, Arthur I. Skoultchi, and Gordon F. Tomaselli}

Address correspondence to: Johanna P. Daily, Albert Einstein College of Medicine, Michael F. Price Center, Room 502, 1301 Morris Park Ave., New York, New York 10461, USA. Email: Johanna.Daily@ einsteinmed.org.

1. Xu C, et al. Nociceptors protect sickle cell disease mice from vaso-occlusive episodes and chronic organ damage. J Exp Med. 2021;218(1):e20200065.

2. Manwani D, et al. Randomized phase 2 trial of intravenous gamma globulin (IVIG) for the treat- ment of acute vaso-occlusive crisis in patients with sickle cell disease: lessons learned from the midpoint analysis. Complement Ther Med. 2020;52:102481.

3. Zhang D, et al. Neutrophil ageing is regulated by the microbiome. Nature. 2015;525(7570):528-532.

4. Jang JE, et al. CXCL1 and its receptor, CXCR2, mediate murine sickle cell vaso-occlusion during hemolytic transfusion reactions. JClin Invest. 2011;121(4):1397-1401.

5. Hidalgo A, et al. Heterotypic interactions enabled by polarized neutrophil microdomains mediate thromboinflammatory injury. Nat Med. 2009;15(4):384-391.

6. Turhan A, et al. Primary role for adherent leukocytes in sickle cell vascular occlusion: a new paradigm. Proc Natl Acad Sci US A. 2002;99(5):3047-3051.

7. Renders S, et al. Niche derived netrin-1 regulates hematopoietic stem cell dormancy via its receptor neogenin-1. Nat Commun. 2021;12(1):608

8. Gao X, et al. Nociceptive nerves regulate haematopoietic stem cell mobilization. Nature. 2021;589(7843):591-596.

9. Wei Q, et al. Snai2 maintains bone marrow niche cells by repressing osteopontin expression. Dev Cell. 2020;53(5):503-513

10. Nakahara F, et al. Engineering a haematopoietic stem cell niche by revitalizing mesenchymal stromal cells. Nat Cell Biol. 2019;21(5):560-567.

11. Xu C, et al. Stem cell factor is selectively secreted by arterial endothelial cells in bone marrow. Nat Commun. 2018;9(1):2449.

12. Hidalgo A, et al. Functional selectin ligands mediating human CD34(+) cell interactions with bone marrow endothelium are enhanced postnatally. J Clin Invest. 2002;110(4):559-569.

13. Zahalka AH, et al. Adrenergic nerves activate an angio-metabolic switch in prostate cancer. Science. 2017;358(6361):321-326.

14. Magnon C, et al. Autonomic nerve development contributes to prostate cancer progression. Science. 2013;341(6142):1236361. 